\begin{tabular}{|c|c|}
\hline $\begin{array}{l}\text { Герич Роман Петрович - кандидат медичних } \\
\text { наук, доцент, ДВНЗ "Прикарпатський національ- } \\
\text { ний університет імені Василя Стефаника" (Івано- } \\
\text { Франківськ, Україна) }\end{array}$ & $\begin{array}{l}\text { Herych Roman Petrovych - Candidate of Science } \\
\text { (Medicine), Associate Professor (Ph. D.), Vasyl Ste- } \\
\text { fanyk Precarpathian National University (Ivano- } \\
\text { Frankivsk, Ukraine) }\end{array}$ \\
\hline \multicolumn{2}{|l|}{ http://orcid.org/0000-0003-4527-4972 } \\
\hline $\begin{array}{l}\text { Лісовський Богдан Петрович - кандидат біоло- } \\
\text { гічних наук, доцент, ДВНЗ “Прикарпатський на- } \\
\text { ціональний університет імені Василя Стефаника" } \\
\text { (Івано-Франківськ, Україна) }\end{array}$ & $\begin{array}{l}\text { Lisovskyi Bohdan Petrovych - Candidate of Science } \\
\text { (Biology), Associate Professor (Ph. D.), Vasyl Ste- } \\
\text { fanyk Precarpathian National University (Ivano- } \\
\text { Frankivsk, Ukraine) }\end{array}$ \\
\hline \multicolumn{2}{|l|}{$\begin{array}{l}\text { e-mail: lisovsky.bogdan @ gmail.com } \\
\text { https://orcid.org/0000-0003-0474-9572 }\end{array}$} \\
\hline $\begin{array}{l}\text { Наконечна Свімлана Павлівна - аспірант, ДВН3 } \\
\text { "Прикарпатський національний університет імені } \\
\text { Василя Стефаника" }\end{array}$ & $\begin{array}{l}\text { Nakonechna Svitlana Pavlivna - post-graduate stu- } \\
\text { dent, Vasyl Stefanyk Precarpathian National Univer- } \\
\text { sity (Ivano-Frankivsk, Ukraine) }\end{array}$ \\
\hline
\end{tabular}

УДК 378.147.091.31-051:796:005.32

doi: 10.15330/fcult.33.19-26

Аліна Боднар, Юрій Юрчишин, Іван Стасюк

\title{
АНАЛІЗ ДИНАМІКИ СФОРМОВАНОСТІ МОТИВАЦЙННГО КОМПОНЕНТУ ГОТОВНОСТІ МАЙБУТНІХ УЧИТЕЛІВ ФІЗИЧНОЇ КУЛЬТУРИ ДО ОЛІМПІЙСЬКОї ОСВІТИ МОЛОДШИХ ШКОЛЯРІВ
}

Мета: Проаналізувати динаміку сформованості мотиваційного компоненту готовності майбутніх учителів фізичної культури до олімпійської освіти на констатувальному етапі та після завершення формувального етапу педагогічного експерименту.

Матеріал і методи: У дослідженні приймали участь 181 майбутніх учителів фізичної культури (88 студентів у складі експериментальних груп i 93 студенти контрольних груп). Для перевірки вірогідності відмінностей між рівнями готовності студентів експериментальних і контрольних груп нами використовувався критерій Пірсона $\left(X^{2}\right)$ який застосовують у непараметричних (якісних) вимірюваннях.

Отримані результати та висновки. Аналіз результатів педагогічного експерименту засвідчив, що за мотивачійним компонентом в експериментальній групі 93,2\% студентів досягнули високого $i$ середнього рівнів досліджуваної готовності проти 77,3\% на початку експерименту в той час як $у$ контрольній групі 87,1\% студентів досягли високого і середнього рівнів проти 76,3\% на початку експерименту.

Ключові слова: мотивачія, майбутні учителі фізичної культури, підготовка, олімпійська освіта.

Objectives: To analyze the dynamics of formation of motivational component of future teachers of physical education for the Olympic education at the stage of formation and after the completion of the formative stage of the pedagogical experiment.

Material and methods: 181 future teachers of physical education participated in the study (88 students in experimental groups and 93 students in control groups). The experimental groups consisted of students of the Faculty of Physical Education of Kamianets-Podilskyi Ivan Ohienko National University (40 persons) and students of Chernivtsi National University (48 persons), and the control groups included students of Ternopil Volodymyr Hnatyuk National Pedagogical University (23 persons ) and H.S. Skovoroda Kharkiv National Pedagogical University (70 persons). To test the probability of differences between the levels of readiness of students in experimental and control groups, we took into consideration the Pearson $\left(X^{2}\right)$ criterion which is used in nonparametric (qualitative) measurements.

Results and conclusions. The analysis of the results of the pedagogical experiment showed positive changes in the level of formation of the motivational component of readiness of future teachers of physical education for the Olympic education of primary schoolchildren who were part of the experimental group compared to the control group. Thus, based on the motivational component in the experimental group, 93.2\% of the students achieved high and average levels of readiness compared with $77.3 \%$ at the start of the experiment, while $87.1 \%$ of students of the control group reached high and average levels against $76.3 \%$ at the beginning of the experiment. 
Proceeding from the above-mentioned, we can state that the application of the developed and theoretically grounded technology of forming the readiness of future teachers of physical culture for the Olympic education of primary pupils into the educational process of students of the experimental group ensured the achievement of significant results in the formation of the motivational component.

Key words: motivation, future physical education teachers, readiness, olympic education.

Постановка проблеми й аналіз результатів останніх досліджень. Підготовка майбутніх фахівців вищих навчальних закладів не може відповідати сучасним вимогам, якщо вони оволоділи тільки знаннями і уміннями, але не розвинули потребу у творчій, пізнавальній і професійній діяльності [1, с. 53]. Важливе місце у підготовці майбутніх учителів фізичної культури належить розвитку пізнавальних інтересів та трансформації їх у професійні мотиви. Саме тому в контексті підготовки майбутніх учителів фізичної культури до олімпійської освіти молодших школярів велика увага приділяється формуванню позитивної мотивації щодо впровадження олімпійської освіти в навчальновиховний процес молодших школярів.

У педагогіці під час дослідження різних видів діяльності за основу беруть характеристику готовності як складової структури, до складу якої входить мотиваційна складова, яку науковці визначають як: мотиваційно-вольовий компонент [2, с. 8]; комунікативно-мотиваційний компонент [3, с. 13]; мотиваційний компонент [4, с. 104] та ін.

Багато дослідників і спеціалістів у галузі олімпійської освіти стверджують, що основою готовності фахівця в галузі олімпійської освіти $є$ не тільки сформована система олімпійських знань а й позитивна мотивація щодо їх використання у своєму стилі життя і в професійній діяльності.

Аналізуючи структуру готовності майбутнього вчителя фізичної культури до олімпійської освіти молодших школярів яка складається із мотиваційного, когнітивного, діяльнісного та рефлексивного компонентів, ми вирішили більш детально зупинитися на характеристиці мотиваційного компоненту зазначеної готовності.

Н. Клименко визначає поняття “мотив”, як інтегральний спосіб організації активності людини, будь-яка iї спонука, так і зовнішні причини.., він виконує селективну, когнітивну, потребову, регулятивно-виконавчу, спонукальну та змістово-формуючу функції. Під мотивом навчальної діяльності автор розуміє всі фактори, які зумовлюють активацію навчальної діяльності студентів: потреби, цілі, установки, обов'язки, інтереси. Серед пізнавальних мотивів учений виокремлює: внутрішні мотиви, які виникли завдяки змісту і процесу навчання у ВНЗ (професійні та пізнавальні мотиви); зовнішні мотиви, що залежать від чинників, котрі знаходяться поза навчальною діяльністю (соціальні мотиви, особистісні мотиви, орієнтовані на досягнення успіху та на запобігання невдач) [5, с. 5].

Поняття “мотив” Л. Міхеєва тлумачить, як складне інтегральне психічне утворення, кінцевою метою якого є формування навчально-пізнавальної активності студентів та спонукання їх до досягнення встановленої мети. До внутрішніх мотивів, на думку ученої, належить пізнавальний (прагнення до оволодіння новими знаннями і способами пізнавальної діяльності), інтерес до знань (прагнення до засвоєння способів отримання знань), мотив самовдосконалення (прагнення до підвищення власної компетентності, ефективності і майстерності), мотив самовипробовування. Зовнішні мотиви, як стверджує автор, безпосередньо не стосуються змісту, процесу і результатів навчальної діяльності, проте відіграють важливу стимулюючу роль [6, с. 5].

I. Усков визначає поняття “мотивація навчальної діяльності”, як сукупність мотивів, що в процесі взаємодії детермінують активність суб'єкта в освітньому процесі і забезпечують професійну спрямованість саморозвитку. Особливостями мотивації навчальної діяльності студентів, на думку автора, є тенденція до домінування мотивів 
оволодіння професією; поява прагнення до отримання освіти, цікавої роботи, посилення установки на гарні життєві умови і матеріальну забезпеченість через професійну діяльність; тісне переплетення пізнавальних мотивів 3 мотивами професійного самовизначення [7, с. 11].

Мотивація $є$ важливим компонентом готовності завдяки впливу на створення необхідних установок і досвіду особистості, професійно значущих якостей, досконалості у діяльності, майстерності, що забезпечують свідоме здійснення діяльності [8, с. 227]. Активація навчально-пізнавальної діяльності студентів та їх зацікавленість процесом і результатами навчальної праці забезпечуються не окремими фрагментарними заходами, а якісною організацією всіх компонентів навчального процесу: цільового, мотиваційно-стимулюючого, змістового, операційно діяльнісного, контрольнорегулюючого та оцінювально-результативного [9, с. 11].

Спираючись на зазначені методологічні основи, можна конкретизувати зміст мотиваційного компоненту готовності, який визначається: характером соціально-значущих мотивів до формування гармонійно розвиненої особистості молодших школярів засобами олімпійської освіти; повнотою уявлення своєї професійної діяльності; усвідомленням своєї соціальної відповідальності; мотивацією досягнення успіху у професії; ступенем турботи про своє особисте і професійне зростання; бажання досягти нових педагогічних цілей.

Мета дослідження. Визначити рівні сформованості мотиваційного компоненту готовності майбутніх учителів фізичної культури до олімпійської освіти на констатувальному та після завершення формувального етапу педагогічного експерименту.

Методи й організація дослідження. 3 метою визначення у студентів рівнів готовності до олімпійської освіти молодших школярів було розроблено діагностичний пакет. Відповідно до цього з представниками контрольних та експериментальних груп під час констатувального та формувального експерименту було проведене письмове опитування та письмове тестування студентів.

До експерименту було залучено 181 майбутніх учителів фізичної культури (88 студентів у складі експериментальних груп і 93 студенти контрольних груп). До експериментальних груп входили студенти факультету фізичної культури Кам'янець-Подільського національного університету імені Івана Огієнка (40 осіб), та студенти Чернівецького національного університету (48 осіб), а до контрольних груп - студенти Тернопільського національного педагогічного університету імені В. Гнатюка (23 особи) та Харківського національного педагогічного університету імені Г. С. Сковороди (70 осіб).

Реалізація педагогічних умов формування готовності майбутніх учителів фізичної культури до олімпійської освіти молодших школярів супроводжувалося педагогічним моніторингом, в процесі якого був розроблений діагностичний інструментарій для дослідження динаміки формування готовності майбутніх учителів фізичної культури до олімпійської освіти молодших школярів.

3 метою кількісної оцінки якісних показників, що були одержані в процесі вимірювання готовності майбутніх учителів фізичної культури до олімпійської освіти молодших школярів були використані методи математичної статистики. Через обробку даних, їх графічне зображення ми опрацювали результати одержані в процесі проведення педагогічного експерименту та перевірили їх вірогідність (достовірність). До початку педагогічного експерименту необхідно було провести початковий діагностичний зріз, що передбачав вимірювання вихідного рівня готовності майбутніх учителів фізичної культури до олімпійської освіти молодших школярів у студентів експериментальної і контрольної груп для подальшого дослідження динаміки. 
Для визначення ефективності експериментальної динаміки на початку і в кінці дослідження була оцінена статистична вірогідність (достовірність) різниці у сформованості мотиваційного компоненту готовності майбутніх учителів фізичної культури експериментальних і контрольних груп до олімпійської освіти молодших школярів.

Для перевірки вірогідності відмінностей між рівнями готовності студентів експериментальних і контрольних груп нами використовувався критерій Пірсона $\left(X^{2}\right)$ який застосовують у непараметричних (якісних) вимірюваннях.

Для розрахунку вірогідності відмінностей результати, одержані в обох групах, розподілялися в багатопільну таблицю.

Рівень готовності майбутніх учителів фізичної культури до олімпійської освіти молодших школярів вимірювався за трьома рівнями: високий, середній, низький.

На основі даних багатопільної таблиці визначалась вірогідність відмінностей між даними експериментальної і контрольної груп на початку експерименту за такою формулою:

$$
X^{2}=\frac{1}{n_{e} \cdot n_{k}} \sum_{i=1}^{c} \frac{\left(n_{e} \cdot K_{i}-n_{k} \cdot E_{i}\right)}{E_{i}+K_{i}},
$$

де $n_{e}-$ кількість досліджуваних в експериментальній групі;

$n_{k}-$ кількість досліджуваних в контрольній групі;

$E_{i}, K_{i}-$ значення колонок (1-3) у таблиці.

Результати і дискусія.

У таблиці 1 зазначені показники рівнів сформованості готовності майбутніх учителів майбутніх учителів фізичної культури до олімпійської освіти молодших школярів за мотиваційним компонентом на констатувальному етапі педагогічного експерименту.

Таблиияя 1

Показники сформованості мотиваційного компоненту готовності майбутніх учителів фізичної культури до олімпійської освіти молодших школярів

(констатувальний експеримент)

\begin{tabular}{|c|c|c|c|c|c|c|c|c|}
\hline \multirow[b]{2}{*}{$\begin{array}{c}\text { Рівні } \\
\text { сформованості }\end{array}$} & \multicolumn{3}{|c|}{$\begin{array}{c}\text { Експериментальна } \\
\text { група } \\
88 \text { осіб } \\
\end{array}$} & \multicolumn{3}{|c|}{$\begin{array}{l}\text { Контрольна } \\
\text { група } \\
93 \text { особи } \\
\end{array}$} & \multirow{2}{*}{$\begin{array}{l}X_{\text {отримане }}^{2} \\
<X_{\text {критичне }}^{2}\end{array}$} & \multirow[b]{2}{*}{ 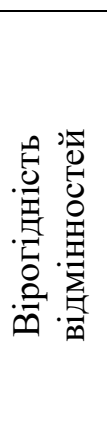 } \\
\hline & 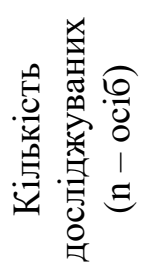 & 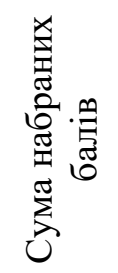 & $\%$ & 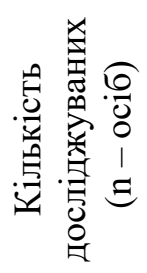 & 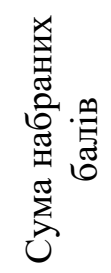 & $\%$ & & \\
\hline Низький & 20 & $0-11$ & 22,7 & 22 & $0-11$ & 23,7 & \multirow{3}{*}{$0,04<6,0$} & \multirow{3}{*}{ немає } \\
\hline Середній & 52 & $12-20$ & 59,1 & 55 & $12-20$ & 59,1 & & \\
\hline Високий & 16 & $21-30$ & 18,2 & 16 & $21-30$ & 17,2 & & \\
\hline
\end{tabular}

Одержані дані вказують, що на початок педагогічного експерименту статистично значимих відмінностей між показниками мотиваційного компоненту досліджуваних експериментальної і контрольної груп немає $X_{\text {омримане }}^{2}<X_{\text {критине }}^{2}(0,04<6,0)$.

Аналізуючи одержані дані можна зробити висновок про те, що готовність майбутніх учителів фізичної культури до олімпійської освіти молодших школярів у мотиваційному аспекті на 1-му курсі навчання частково сформована. Аналіз результатів анкетування студентів експериментальних і контрольних груп свідчить про позитивне 
відношення щодо реалізації олімпійської освіти молодших школярів. Вони проявляють впевненість у тому, що ця діяльність $є$ необхідна. Проте, при цьому активність більшості майбутніх учителів у накопиченні досвіду відповідної діяльності залишається низькою.

В експериментальній групі 22,7\% досліджуваних мають низький рівень сформованості мотиваційного компоненту, 59,1\% студентів - середній рівень, 18,2\% - високий рівень; у контрольній групі: $23,7 \%$ студентів мають низький рівень, 59,1\% - середній, $17,2 \%$ - високий рівень. I це зрозуміло, адже учасниками констатувального етапу педагогічного експерименту були першокурсники.

Загалом, виявлені у процесі констатувального експерименту рівні сформованості готовності студентів експериментальної у контрольної груп до олімпійської освіти молодших школярів дали підставу для розробки технології формування готовності майбутніх учителів фізичної культури до олімпійської освіти молодших школярів та впровадження іiі у навчально-виховний процес студентів факультетів фізичної культури 3BO.

3 цією метою було проведено формувальний етап експерименту. Після проведення експериментальної роботи були проведені зрізи аналогічні тим, що проводились під час констатувального етапу експерименту.

Розглянемо динаміку рівнів готовності студентів експериментальної і контрольної груп до олімпійської освіти молодших школярів за мотиваційним компонентом після завершення контрольного етапу експерименту (табл. 2)

Табличя 2

Показники сформованості мотиваційного компоненту

готовності майбутніх учителів фізичної культури до олімпійської освіти молодших школярів після завершення формувального етапу експерименту

\begin{tabular}{|c|c|c|c|c|c|c|c|c|}
\hline \multirow[b]{2}{*}{$\begin{array}{c}\text { Рівні } \\
\text { сформованості }\end{array}$} & \multicolumn{3}{|c|}{$\begin{array}{c}\text { Експериментальна } \\
\text { група } \\
88 \text { осіб } \\
\end{array}$} & \multicolumn{3}{|c|}{$\begin{array}{c}\text { Контрольна } \\
\text { група } \\
93 \text { особи } \\
\end{array}$} & \multirow{2}{*}{$\begin{array}{l}X_{\text {отримане }}^{2} \\
>X_{\text {критичне }}^{2}\end{array}$} & \multirow[b]{2}{*}{ 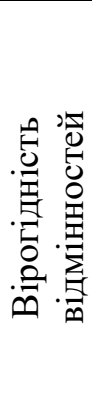 } \\
\hline & 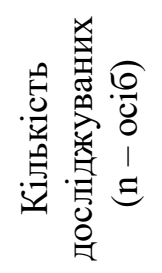 & 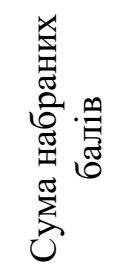 & $\%$ & 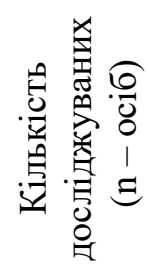 & 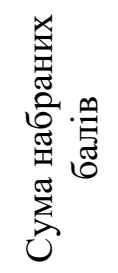 & $\%$ & & \\
\hline Низький & 6 & $0-11$ & 6,8 & 12 & $0-11$ & 12,9 & \multirow{3}{*}{$11,12>6,0$} & \multirow{3}{*}{$\epsilon$} \\
\hline Середній & 38 & $12-20$ & 43,2 & 57 & $12-20$ & 61,3 & & \\
\hline Високий & 44 & $21-30$ & 50 & 24 & $21-30$ & 25,8 & & \\
\hline
\end{tabular}

Дані одержані в результаті дослідження, вказують на те, що після завершення педагогічного експерименту між показниками мотиваційного компоненту досліджуваних експериментальної та контрольної груп існують статистично значимі відмінності $X_{\text {отримане }}^{2}>X_{\text {критичне }}^{2}(11,12>6,0)$.

У контрольній групі за результатами констатувального експерименту низький рівень готовності за мотиваційним компонентом склав $23,7 \%$, після завершення формувального етапу експерименту 12,9\%, відповідно середній рівень - 59,1\% і 61,3\% і високий рівень - 17,2\% і 26,8\% досліджуваних.

В експериментальній групі на початку педагогічного експерименту низький рівень склав $22,7 \%$, після завершення формувального етапу експерименту $6,8 \%$, середній відповідно - 59,1\% і 43,2\%, і високий за результатами констатувального експери- 
менту $18,2 \%$, після завершення формувального етапу педагогічного експерименту $50 \%$ респондентів.

Проаналізуємо динаміку рівнів сформованості готовності студентів експериментальної групи до олімпійської освіти молодших школярів за мотиваційним компонентом (табл. 3).

Таблиия 3

Показники сформованості готовності студентів експериментальної групи до олімпійської освіти молодших школярів за мотиваційним компонентом

\begin{tabular}{|c|c|c|c|c|c|c|}
\hline \multirow[b]{3}{*}{$\begin{array}{c}\text { Рівні } \\
\text { сформованості }\end{array}$} & \multicolumn{4}{|c|}{ Етапи педагогічного експерименту } & \multirow{3}{*}{$\begin{array}{l}X_{\text {отримане }}^{2} \\
>X_{\text {критичне }}^{2}\end{array}$} & \multirow{3}{*}{ 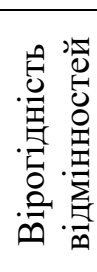 } \\
\hline & \multicolumn{2}{|c|}{ констатувальний } & \multicolumn{2}{|c|}{ контрольний } & & \\
\hline & $\begin{array}{c}\text { Абсолютна } \\
\text { кількість } \\
\text { студентів } \\
\text { (n-осіб) }\end{array}$ & $\begin{array}{c}\text { Відносна } \\
\text { кількість } \\
\text { студентів } \\
\%\end{array}$ & $\begin{array}{c}\text { Абсолютна } \\
\text { кількість } \\
\text { студентів } \\
\text { (n-осіб) }\end{array}$ & $\begin{array}{c}\text { Відносна } \\
\text { кількість } \\
\text { студентів } \\
\%\end{array}$ & & \\
\hline Низький & 20 & 22,7 & 6 & 6,8 & & \\
\hline Середній & 52 & 59,1 & 38 & 43,2 & $21,12>6,0$ & $\epsilon$ \\
\hline Високий & 16 & 18,2 & 44 & 50 & & \\
\hline
\end{tabular}

Результати аналіз уданих (табл. 3) свідчать про наявність вірогідних відмінностей між рівнями сформованості мотиваційного компоненту готовності студентів експериментальної групи до початку i після завершення педагогічного експерименту $X_{\text {отримане }}^{2}>X_{\text {критичие }}^{2}(21,12>6,0)$.

Як свідчать результати аналізу одержаних експериментальних даних (табл. 4) у контрольній групі спостерігається позитивна динаміка рівнів сформованості готовності студентів до олімпійської освіти молодших школярів за мотиваційним компонентом хоча вірогідних відмінностей між показниками констатувального і контрольного етапів немає $X_{\text {отримане }}^{2}<X_{\text {критичне }}^{2}(4,8<6,0)$.

Таблиия 4

Показники сформованості готовності студентів контрольної групи до олімпійської освіти молодших школярів за мотиваційним компонентом

\begin{tabular}{|c|c|c|c|c|c|c|}
\hline \multirow[b]{3}{*}{$\begin{array}{c}\text { Рівні } \\
\text { сформованості }\end{array}$} & \multicolumn{4}{|c|}{ Етапи педагогічного експерименту } & \multirow[b]{3}{*}{$\begin{array}{l}X_{\text {отримане }}^{2} \\
<X_{\text {критичне }}^{2}\end{array}$} & \multirow{3}{*}{ 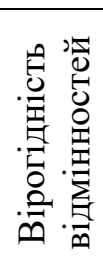 } \\
\hline & \multicolumn{2}{|c|}{ констатувальний } & \multicolumn{2}{|c|}{ контрольний } & & \\
\hline & $\begin{array}{c}\text { Абсолютна } \\
\text { кількість } \\
\text { студентів } \\
\text { (n-осіб) }\end{array}$ & $\begin{array}{c}\text { Відносна } \\
\text { кількість } \\
\text { студентів } \\
\%\end{array}$ & $\begin{array}{c}\text { Абсолютна } \\
\text { кількість } \\
\text { студентів } \\
\text { (n-осіб) }\end{array}$ & $\begin{array}{c}\text { Відносна } \\
\text { кількість } \\
\text { студентів } \\
\%\end{array}$ & & \\
\hline Низький & 22 & 23,7 & 12 & 12,9 & & \\
\hline Середній & 55 & 59,1 & 57 & 61,3 & $4,8<6,0$ & немає \\
\hline Високий & 16 & 17,2 & 24 & 25,8 & & \\
\hline
\end{tabular}

Висновок. Таким чином, підсумковий аналіз і узагальнення результатів педагогічного експерименту підтвердив наявність позитивних змін рівня сформованості мотиваційного компоненту готовності майбутніх учителів фізичної культури до олімпійської освіти молодших школярів, що входили до експериментальної групи порівняно 3 контрольною.

Так, за мотиваційним компонентом в експериментальній групі 93,2\% студентів досягнули високого і середнього рівнів досліджуваної готовності проти 77,3\% на початку експерименту в той час як у контрольній групі 87,1\% студентів досягли високого і середнього рівнів проти 76,3\% на початку експерименту. 
Виходячи із вищезазначеного, можна констатувати, що впровадження розробленої і теоретично обгрунтованої нами технології формування готовності майбутніх учителів фізичної культури до олімпійської освіти молодших школярів у навчально-виховний процес студентів експериментальної групи забезпечило досягнення вагомих результатів.

Подальші дослідження будуть спрямовані на аналіз результатів динаміки сформованості когнітивного, діяльнісного та рефлексивного компонентів готовності майбутніх учителів фізичної культури.

1. Петров ПК. Система подготовки будущих специалистов физической культуры в условиях информатизации образования [автореферат дисертации]. Ижевск: Удмурт. гос. ун-т; 2004. 40 с.

2. Бродська ЛВ. Формування готовності майбутніх учителів іноземної мови до виховної роботи в школі [автореферат дисертації]. Київ: Інститут вищої освіти АПН України; 2006. 20 с.

3. Галицька ММ. Формування у студентів вищих навчальних закладів сфери туризму готовності до іншомовного спілкування [автореферат дисертації]. Київ: Національний педагогічний ун-т ім. М.П. Драгоманова; 2007. $20 \mathrm{c}$.

4. Соглаев ВВ. Педагогические условия формирования готовности курсантов ввуза к воспитательной деятельности [дисертація]. Челябинск; 1997. 222 с.

5. Кобзар Б. Педагогічні системи, педагогічні процеси й педагогічні технології. Наукові записки. Серія: Педагогічні науки. 2001. 32: 47-50.

6. Міхеєва ЛВ. Формування мотивації вивчення педагогічних дисциплін майбутніми вчителями праці і професійного навчання [автореферат дисертації]. Вінниця. Вінницький держ. педагогічний ун-т ім. Михайла Коцюбинського; 2005. 20 с.

7. Усков ИВ. Информационно-коммуникативные технологии как средство развития мотивации учебной деятельности студентов [автореферат дисертации]. Рязань. 2006. 22 с.

8. Фунтікова ОО. Педагогіка вищої школи. Словник-довідник. Запоріжжя: ГУ “ЗІДМУ”; 2007. 407 с.

9. Смирнова ЕЭ. Пути формирования модели специалиста с высшим образованием. Ленинград: Издательство Ленинградского университета; 1977. 136 с.

\section{References}

1. Petrov PK. Sistema podgotovki buduschih spetsialistov fizicheskoy kulturyi v usloviyah informatizatsii obrazovaniya [avtoreferat disertatsii]. Izhevsk: Udmurt. gos. un-t; 2004. $40 \mathrm{~s}$.

2. Brodska LV. Formuvannia hotovnosti maibutnikh uchyteliv inozemnoi movy do vykhovnoi roboty v shkoli [avtoreferat dysertatsii]. Kyiv: Instytut vyshchoi osvity APN Ukrainy; 2006. $20 \mathrm{s.}$

3. Halytska MM. Formuvannia u studentiv vyshchykh navchalnykh zakladiv sfery turyzmu hotovnosti do inshomovnoho spilkuvannia [avtoreferat dysertatsii]. Kyiv: Natsionalnyi pedahohichnyi un-t im. M.P.Drahomanova; 2007. $20 \mathrm{~s}$.

4. Petrov PK. Sistema podgotovki buduschih spetsialistov fizicheskoy kulturyi v usloviyah informatizatsii obrazovaniya [avtoreferat disertatsii]. Izhevsk: Udmurt. gos. un-t; 2004. $40 \mathrm{~s}$.

5. Kobzar B. Pedahohichni systemy, pedahohichni protsesy y pedahohichni tekhnolohii. Naukovi zapysky. Seriia: Pedahohichni nauky. 2001. 32: 47-50.

6. Mikheieva LV. Formuvannia motyvatsii vyvchennia pedahohichnykh dystsyplin maibutnimy vchyteliamy pratsi i profesiinoho navchannia [avtoreferat dysertatsii]. Vinnytsia. Vinnytskyi derzh. pedahohichnyi un-t im. Mykhaila Kotsiubynskoho; 2005. 20 s.

7. Uskov IV. Informatsionno-kommunikativnyie tehnologii kak sredstvo razvitiya motivatsii uchebnoy deyatelnosti studentov [avtoreferat disertatsii]. Ryazan. 2006. $22 \mathrm{~s}$.

8. Funtikova OO. Pedahohika vyshchoi shkoly. Slovnyk-dovidnyk. Zaporizhzhia: HU "ZIDMU”; 2007. 407 s.

9. Smirnova EE. Puti formirovaniya modeli spetsialista s vyisshim obrazovaniem. Leningrad: Izdatelstvo Leningradskogo universiteta; 1977. $136 \mathrm{~s}$.

\section{Цитування на цю статтю:}

Боднар АO, Юрчишин ЮB, Стасюк II. Аналіз динаміки сформованості мотиваційного компоненту готовності майбутніх учителів фізичної культури до олімпійської освіти молодших школярів. Вісник Прикарпатського університету. Серія: Фізична культура. 2019 Берез 26; 19-26

\begin{tabular}{|c|c|}
\hline Відомості про автора: & Information about the author: \\
\hline $\begin{array}{l}\text { Боднар Аліна Олександрівна - кандидат педа- } \\
\text { гогічних наук, Кам'янець-Подільський національ- }\end{array}$ & $\begin{array}{l}\text { Bodnar Alina Oleksandrivna - Candidate of Science } \\
\text { (Education), Kamianets-Podilskyi National Ivan }\end{array}$ \\
\hline
\end{tabular}




\begin{tabular}{|c|c|}
\hline $\begin{array}{l}\text { ний університет імені Івана Огієнка (Кам'янець- } \\
\text { Подільський, Україна) }\end{array}$ & Ohiienko University (Kamianets-Podilskyi, Ukraina) \\
\hline \multicolumn{2}{|l|}{$\begin{array}{l}\text { e-mail: bodnar.alina@kpnu.edu.ua } \\
\text { https://orcid.org/0000-0002-8921-3656 }\end{array}$} \\
\hline $\begin{array}{l}\text { Юрчишин Юрій Володимирович - кандидат наук } \\
3 \text { фізичного виховання та спорту, доцент, Кам’я- } \\
\text { нець-Подільський національний університет імені } \\
\text { Івана Огієнка (Кам'янець-Подільський, Україна) }\end{array}$ & $\begin{array}{l}\text { Yurchyshyn Yurii Volodymyrovych - Candidate of } \\
\text { Science (Education), Associate Professor (Ph. D.), } \\
\text { Kamianets-Podilskyi National Ivan Ohiienko Uni- } \\
\text { versity (Kamianets-Podilskyi, Ukraina) }\end{array}$ \\
\hline \multicolumn{2}{|l|}{$\begin{array}{l}\text { e-mail: yuriyyurchyshyn @ kpnu.edu. } \\
\text { https://orcid.org/0000-0002-0404-9384 }\end{array}$} \\
\hline $\begin{array}{l}\text { Стасюк Іван Іванович - кандидат наук з фізично- } \\
\text { го виховання та спорту, доцент, Кам'янець-Поділь- } \\
\text { ський національний університет імені Івана Огієн- } \\
\text { ка (Кам'янець-Подільський, Україна) }\end{array}$ & $\begin{array}{l}\text { Stasiuk Ivan Ivanovych - Candidate of Science } \\
\text { (Education), Associate Professor (Ph. D.), Kamianets- } \\
\text { Podilskyi National Ivan Ohiienko University } \\
\text { (Kamianets-Podilskyi, Ukraina) }\end{array}$ \\
\hline $\begin{array}{l}\text { e-mail: stasuik.ivan@ kpnu.edu.ua } \\
\text { https://orcid.org/0000-0002-4504-5902 }\end{array}$ & \\
\hline
\end{tabular}

УДК 378.014.6.093.5:796

doi: 10.15330/fcult.33.26-34
Ірина Бондаренко, Оксана Дзюбан, Геннадій Кураса, Олег Бондаренко

\section{ПРО ЯКІСТЬ ОСВІТНЬОГО ПРОЦЕСУ НА ФАКУЛЬТЕТІ ФІЗИЧНОГО ВИХОВАННЯ І СПОРТУ \\ (на прикладі Чорноморського національного університету імені Петра Могили)}

\footnotetext{
Метою дослідження слугувало підвищення якості освітнього процесу на факультеті фізичного виховання та спорту в ЧНУ імені Петра Могили.

В анкетуванні (2019 р.) взяло участь 158 студентів. Визначено рейтинг провідних мотивів щзодо вибору майбутньої професійної діяльності: власне бажання (33,2\%), престиж професії (15,5\%), можливість подальшого працевлаштування $(13,7 \%)$.

Якість вищої освіти в університеті більшість студентів охарактеризували як “високу” та “дуже високу” (77,2\%). Майже чверть респондентів відмітило (25,3\%), щуо не задоволені критеріями оцінювання. Більшість студентів задоволені рівнем організації та проведення лекцій з профільних (93,1\%) та непрофільних предметів (89,8\%). Більшість опитаних студентів не розчарувалися у виборі щзодо факультету та спеціальності (72,2\%).

Опитування сприяє прочесу двосторонньої взаємодї між викладачами й студентами. Розробляються заходи щзодо вдосконалення робочих програм з непрофільних дисциплін.

Ключові слова: анкетування, студент, спеціальність, мотив, якість освіти.
}

The purpose of the research: to improve the quality of the educational process in higher education at the Faculty of Physical Education and Sports by tracking the attitude of students to the educational process at the Petro Mohyla National University.

Methods of research: The survey was carried out during January-February 2019. The survey was attended by 158 students studying at the Faculty of Physical Education and Sports. The method of analysis of scientific sources and methods of mathematical statistics is applied.

Research results._Students determined the rating of leading motives in choosing future professional activities: their own desire (33.2\%), prestige of the profession (15.5\%), the possibility of further employment (13.7\%).

The quality of higher education at the university was characterized by the majority of students as "high" and "very high" (77.2\%).

More than half of the interviewed students (57.0\%) believe that the criteria for evaluating their knowledge and skills are always transparent and understandable. Almost a quarter of respondents noted (25.3\%) that they are not satisfied with the criteria of evaluation. 